\title{
Histological Validation of Morphochromatically-Defined Gonadal Maturation Stages of Green Abalone (Haliotis fulgens) Philippi, 1845 and Pink Abalone (Haliotis corrugata) Wood, 1828
}

\author{
Validación Histológica de las Fases Morfocromáticas de Maduración Gonádica del Abulón Azul \\ (Haliotis fulgens) Philippi, 1845 y del Abulón Amarillo (Haliotis corrugata) Wood, 1828
}

\author{
Nurenskaya Vélez-Arellano*; Federico Andrés García-Domínguez ${ }^{* * * * * * *}$; Daniel B. Lluch-Cota**; \\ José L. Gutiérrez-González ${ }^{* * *}$ \& Rebeca Sánchez-Cárdenas ${ }^{* * * * *}$
}

VÉLEZ-ARELLANO, N.; GARCÍA-DOMÍNGUEZ, F. A.; LLUCH-COTA, D. B.; GUTIÉRREZ-GONZÁLEZ, J. L. \& SÁNCHEZ-CÁRDENAS, R. Histological validation of morphochromatically-defined gonadal maturation stages of green abalone (Haliotis fulgens) Philippi, 1845 and pink abalone (Haliotis corrugata) Wood, 1828. Int. J. Morphol., 33(3):1054-1059, 2015.

SUMMARY: Identifying the maturity stage of specimens is essential for the determination of the spawning season, which in turn facilitates the formulation of adequate fisheries management measures for the sustainable use of sea resources, such as abalone. This study aims to validate, based on histological evidence, a gonad maturation scale that encompasses four morphochromatically-defined stages (developing, maturity, spawning and resting) for females and males, plus an additional stage for reproductively inactive (undifferentiated) specimens, to be used as an identification key. Given the similarity between Haliotis fulgens and Haliotis corrugata as to their morphochromatic features, the gonadal maturation scale can be used for both species.

KEY WORDS: Assessment tools; Gametogenesis; Gonads; Reproduction.

\section{INTRODUCTION}

Haliotids possess a single gonad that is part of a conical appendage known as hepatogonadal complex, located on the left side of the shell and that can be exposed simply by raising the foot and the epipodium (a sensory structure and extension of the foot that nears tentacles) (Cox, 1962) (Fig. 1). The hepatogonadal complex is conical in shape and consists of two organs: the inner one is the digestive gland (hepatopancreas), while the outer one is the gonad (Cox; Martin et al., 1983) (Fig. 2). Gonad color varies both with the maturity stage and between species; for instance, the testes of Haliotis rufescens Swainson, 1822 display an orange or yellow coloration (Wood, 1993; RogersBennett et al., 2004), while the ovaries of Haliotis cyclobates Péron \& Lesueur 1816, Haliotis laevigata Donovan, 1808, Haliotis roei Gray, 1826, Haliotis ruber Leach 1814 and Haliotis scalaris Leach, 1814 are grey to blue-green (Shepherd \& Laws, 1974).
The position of the gonad within the hepatogonadal complex allows its color to be distinguished from outside, thus making it possible to determine the sex of the specimen examined (beige or cream in males, green in females) (Boolootian et al., 1962; Cox; Martin et al.; Sobhon et al., 1999; Singhakaew et al., 2003; Garcia-Esquivel 2007; Roux et al., 2013; Hadijah et al., 2013) without dissecting it; sometimes it is also possible to infer its maturity stage based on gonad firmness and size.

Both the green (Haliotis fulgens) and the pink (Haliotis corrugata) abalone have been extensively studied and systematically monitored because of their economic importance as a fishery resource in the Mexican Pacific coast. In this context, and in order to validate the use of the morphochromatic scale as a practical tool for the extensive monitoring of green and pink abalone, in this investigation

* Instituto Politécnico Nacional, Centro Interdisciplinario de Ciencias Marinas, La Paz, México

** Centro de Investigaciones Biológicas del Noroeste, La Paz, México.

*** Centro Regional de Investigación Pesquera, La Paz, México.

***** Facultad de Ciencias del Mar, Universidad Autónoma de Sinaloa, Sinaloa, México.

******* Becario COFAA. 


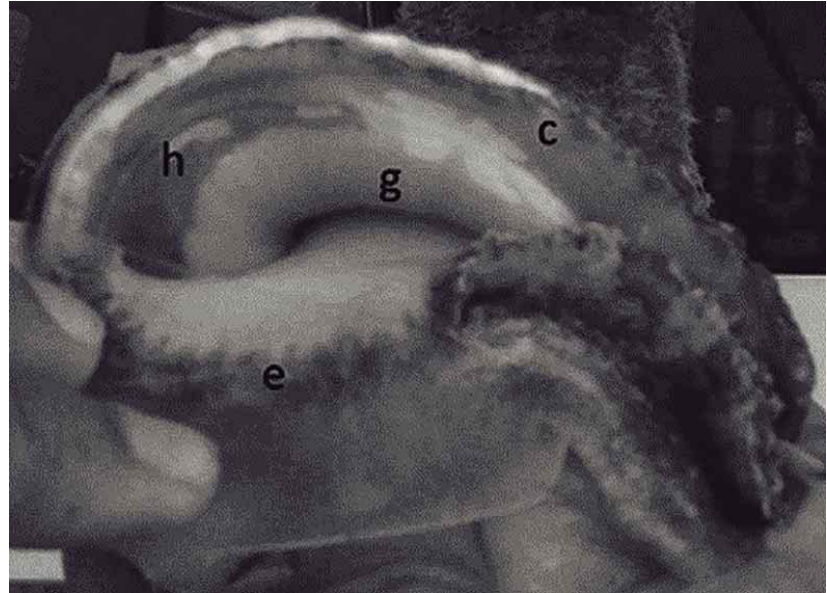

Fig. 1. Live abalone showing the gonad (g) and hepatopancreas (h) over the shell (c), when the epipodius (e) is removed. Photo: fishconsult.org.

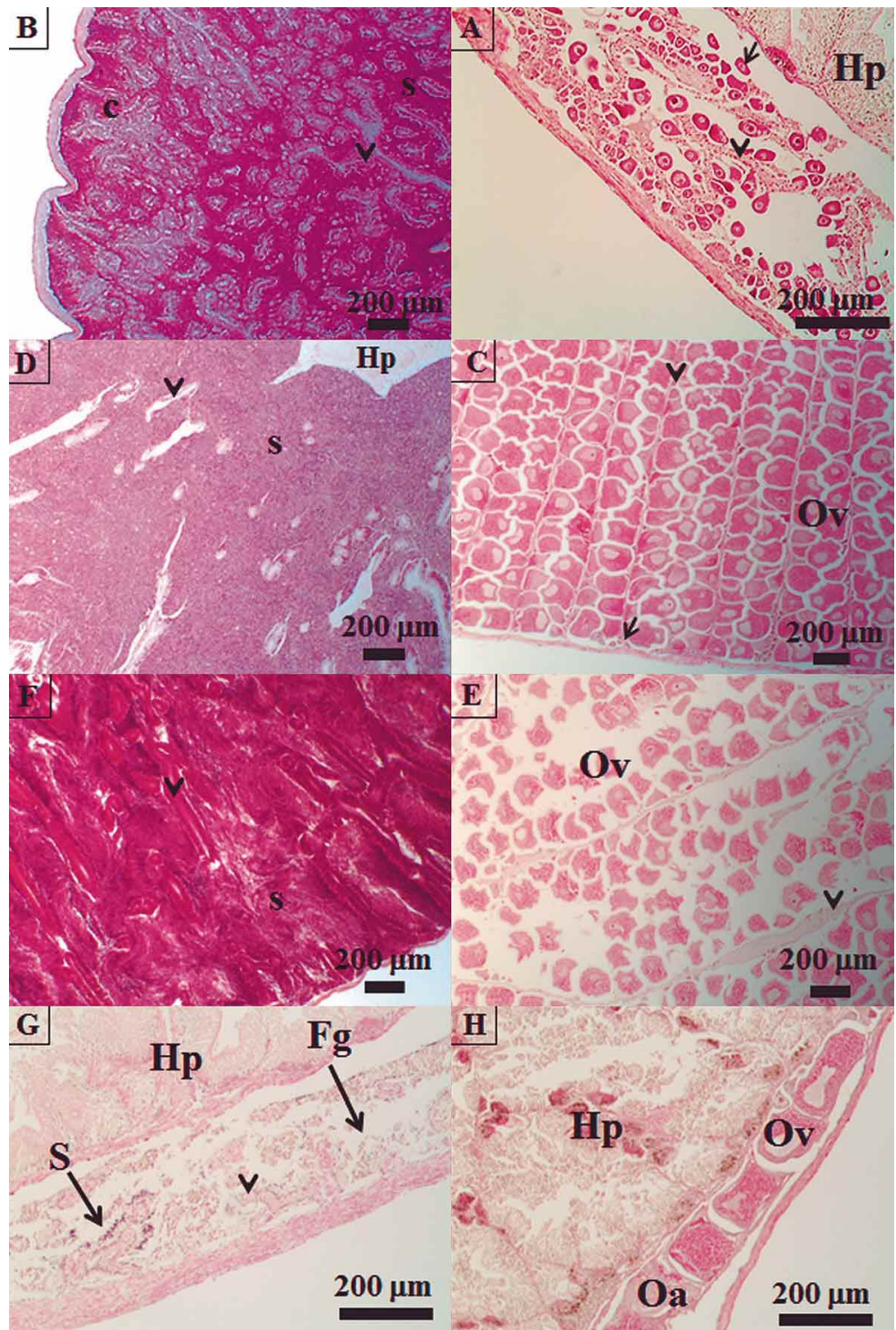

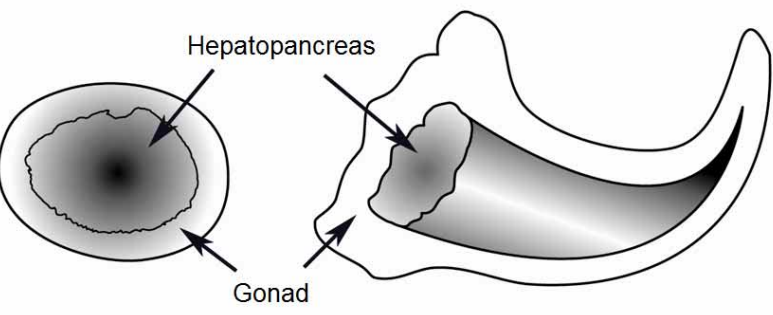

Fig. 2. Scheme of longitudinal and cross-sections of the abalone gonad, showing the hepatopancreas and the gonad surrounding it.

we conducted a histological description of the gonad development stages of $H$. fulgens and $H$. corrugata in relation to the respective morphochromatically-defined stages, as a guideline for identifying the gonad maturation stage of specimens.

\section{MATERIAL AND METHOD}

About 30 specimens of each species (Haliotis fulgens and Haliotis corrugata) were collected monthly from September 2011 through October 2012. The specimens were collected at 0-24 meters depth at the coast of La Bocana $\left(26^{\circ}\right.$ $02^{\prime} 58.61^{\prime \prime} \mathrm{N}, 112^{\circ} 17^{\prime} 07.14^{\prime \prime} \mathrm{W}$ ), Tortugas Bay $\left(27^{\circ} 38^{\prime} 57^{\prime \prime} \mathrm{N}, 114^{\circ} 52^{\prime} 36^{\prime \prime} \mathrm{W}\right)$ and Asuncion Bay $\left(27^{\circ} 06^{\prime} 00^{\prime \prime} \mathrm{N}, 114^{\circ} 18^{\prime} 00^{\prime \prime} \mathrm{W}\right)$ in the State of Baja California Sur. Specimens were dissected to remove the hepatogonadal complex. Each hepatogonadal complex was photographed and examined to describe the gonad color and consistency, as well as its size relative to the hepatopancreas size. Hepatogonadal complexes were then fixed in $10 \%$ formalin and processed following the standard histological technique: they were included in paraffin, and $5 \mathrm{~mm}$-thick sections were obtained and stained with hematoxylin-eosin (Humason, 1979) (Fig. 4). The gonad maturation stage of each specimen was determined based on the amount and type

Fig. 3. Histological images of the different morphochromatic gonad maturation stages in Haliotis fulgens and $H$. corrugata: A) developing female, B) developing male, $\mathrm{C}$ ) mature female, D) mature male, E) spawning female, F) spawning male, G) resting female, $H$ ) resting male. Spermatozoa (S), spermatogonia (C), trabeculae (arrowhead), previtellogenic oocytes (arrow), vitellogenic oocytes $(\mathrm{Ov})$, atresic oocytes (Oa), Hepatopancreas (HP). The bar length represents $200 \mathrm{~mm}$. Hematoxylin-eosin technique. 
of cells in the gonad, following Najmudeen \& Victor (2004) and Setyono (2006).

A total of $535 \mathrm{H}$. fulgens and $552 \mathrm{H}$. corrugata specimens were examined, on which morphochromatic and histological features of gonad maturation were observed. As both species showed similar characteristics, a single scale encompassing four stages (developing, maturity, spawning and resting) of ovaries and testes is described for both species (Table I, Figs. 3 and 5). The hepatogonadal complex of sexually undifferentiated specimens (undifferentiated stage) (Fig. 4) was also described.
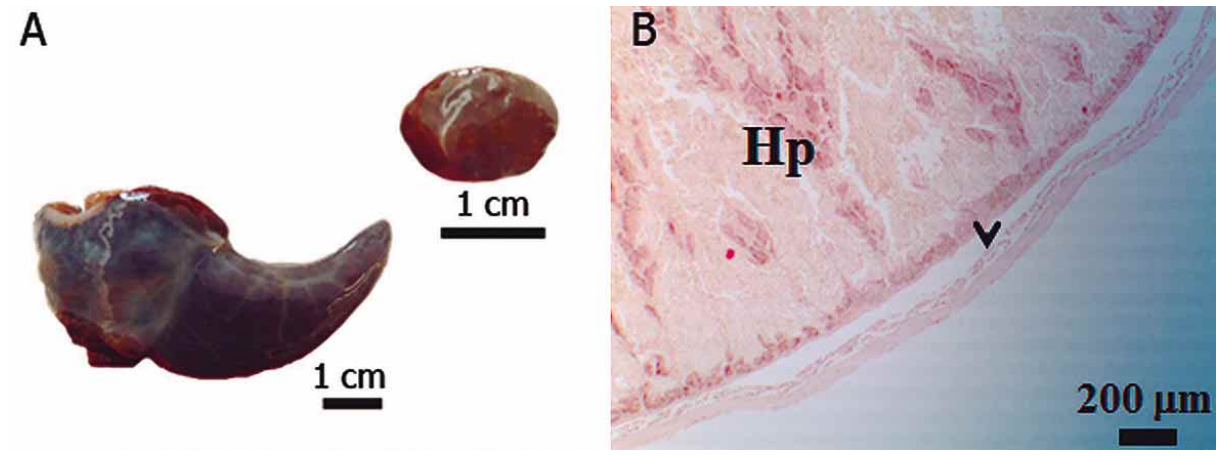

Fig. 4. A) Morphological features of undifferentiated stage of gonads, B) Histological images of undifferentiated stage of gonads, trabeculae (arrowhead), Hepatopancreas (HP). The bar length represents $200 \mathrm{~mm}$. Hematoxylin-eosin technique.

\section{RESULTS}

The gonad shows no evidence of gametogenesis during undifferentiated stage: germ cells located in the epithelium surrounding the hepatogonadal complex have not yet been differentiated into gametes, and the hepatogonadal complex only consists of the hepatopancreas. Externally, the organ has a smooth consistency, flaccid to the touch, and the epithelium and the gonad surrounding it are thin and have an almost transparent whitish appearance, which reveals the nearly black coloration of the underlying hepatopancreas. Its size ranges from 2 to $6 \mathrm{~cm}$ (Fig. 4a) and, in cross-section, the brown hepatopancreas can be observed (Fig. 4b).

Table I. Description of the gonad maturation stages in Haliotis fulgens and H. corrugata.

\begin{tabular}{ll}
\hline Stage & Description \\
Developing & Gonads enter the gametogenesis process. The histological analysis reveals a large number of oogonia and \\
previtellogenic oocytes attached to the trabeculae of connective tissue in females (Fig. 3A); in males, \\
trabeculae appear widened due to the large number of spermatogonia and spermatocytes attac hed to them; \\
spermatozoa can be seen in the gonad lumen (Figure 3B). Externally, the organ is still flaccid and soft, and \\
the basal part of the hepatopancreas has not yet been surrounded by the gonad. The gonad occupies between \\
$4 \%$ and $60 \%$ of the cross-section area. Female gonads have a green khaki color, while male gonads are beige \\
(Figs. 5A and 5B). \\
Mature gonads are fully developed and contain a large number of gametes, which gives them a firm \\
consistency. The histological analysis reveals that female gonads are virtually filled with mature oocytes (Fig. \\
3C), while male gonads have thinned trabeculae covered with spermatozoa (Fig. 3D). The gonad appears as \\
an external sheath fully covering the hepatogonadal complex. The gonadal tissue occupies $60 \%$ to $90 \%$ of the \\
cross-section area. Ovaries have a bright khaki green color and its content has a grainy appearance given by \\
the mature oocytes. Testicles have a nearly white color and are filled with a viscous fluid containing \\
spermatozoa (Figs. 5C and 5D). \\
The gonads show evidence of gamete release (spawning/ejaculation); histological observations reveal gaps \\
above the gonadal tissue (Figs. 3E and 3F). Morphologically, gonads lack consistency, that is, they are \\
flaccid. Externally, the gonad surrounds completely the hepatogonadal complex and shows an opaque khaki \\
color in females and opaque white in males. Gametes spur out from the gonad upon cutting a cross-section of \\
the hepatogonad. The gonad represents between $11 \%$ and $78 \%$ of the cross-section area of the hepatogonadal \\
complex (Figs. 5E and 5F).
\end{tabular}

Resting Following spawning, the gonad is still present in the hepatogonadal complex but only as a thin layer that occupies less than $10 \%$ of its cross-section area. The histological analysis reveals some vitellogenic or atresic oocytes or spermatozoa being reabsorbed by phagocytes (Figs. 3G and 3H). The hepatogonad appears flaccid; its color ranges from gray to khaki with dark brown spots in females, whereas males might display white and brown shades in the same gonad (Figs. $5 \mathrm{G}$ and $5 \mathrm{H}$ ). 
Stage

Developing

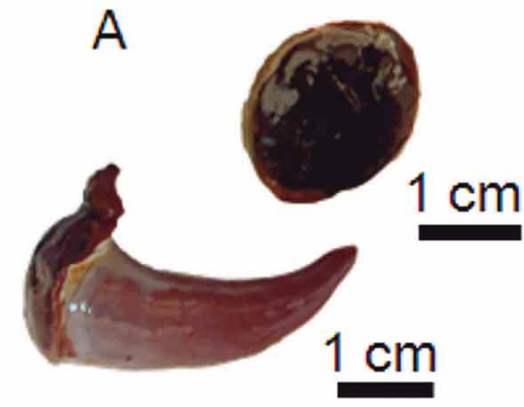

Maturity

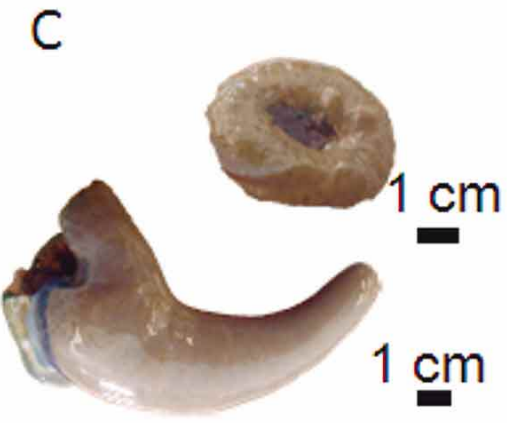

D

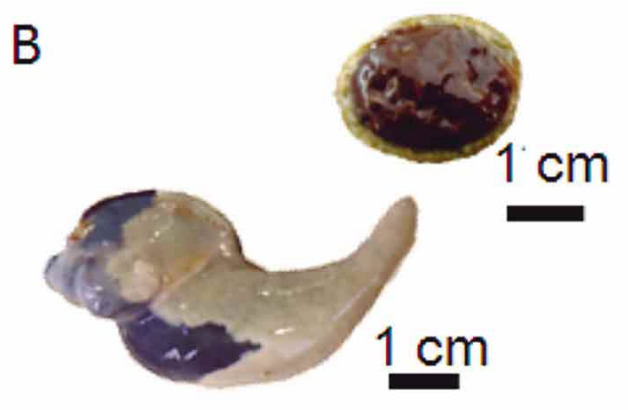

Spawning

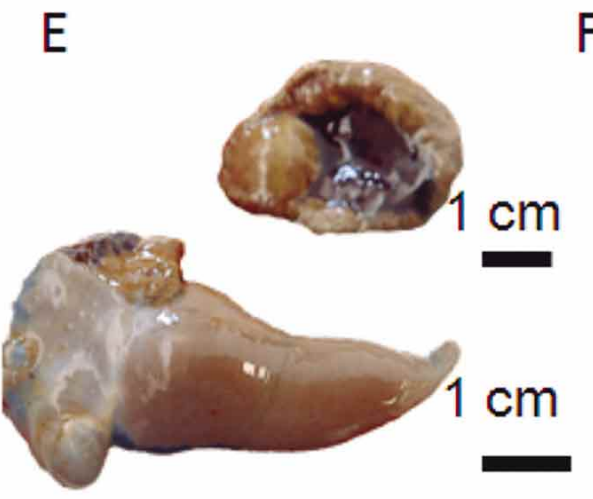

F

Resting

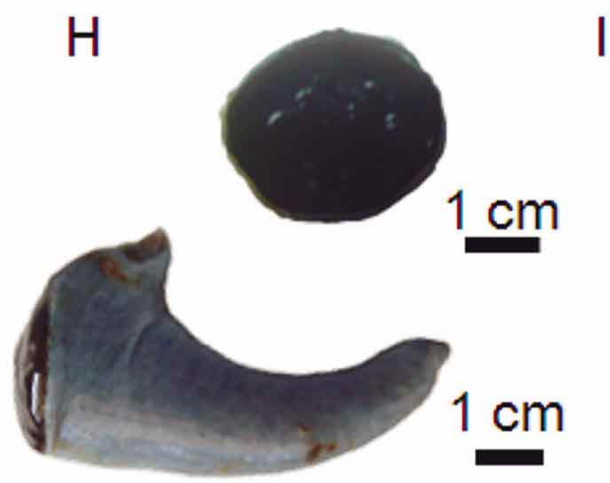

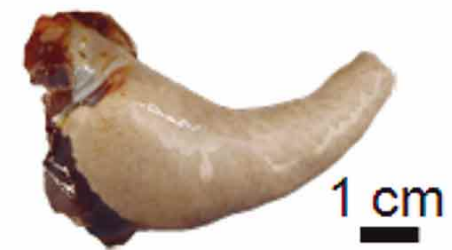

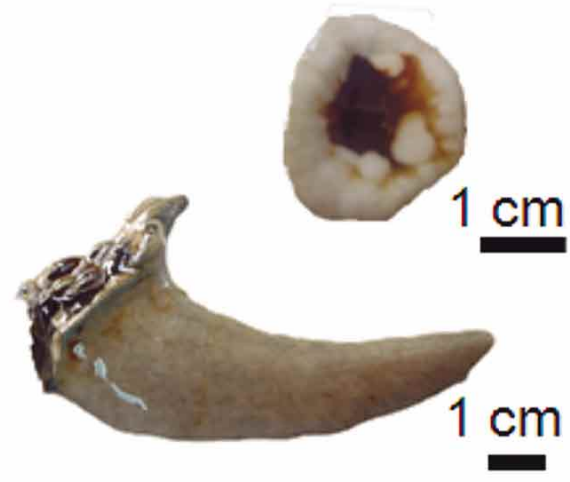

Males

D

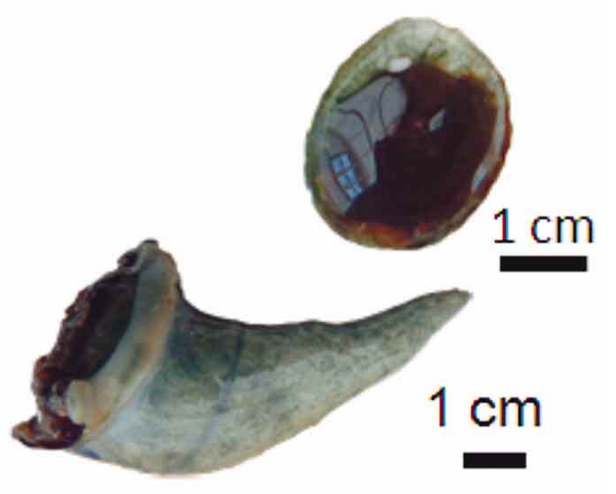

Fig. 5. Morphological features of the different stages of gonad maturation in Haliotis fulgens and H. corrugata: A) developing female, B) developing male, C) mature female, D) mature male, E) spawning female, F) spawning male, G) resting female, H) resting male. To the right hand side of each hepatogonad picture, the corresponding cross-section is shown. 
VÉLEZ-ARELLANO, N.; GARCÍA-DOMÍNGUEZ, F. A.; LLUCH-COTA, D. B.; GUTIÉRREZ-GONZÁLEZ, J. L. \& SÁNCHEZ-CÁRDENAS, R. Histological validation of morphochromatically-defined gonadal maturation stages of green abalone (Haliotis fulgens) Philippi, 1845 and pink abalone (Haliotis corrugata) Wood, 1828. Int. J. Morphol., 33(3):1054-1059, 2015.

\section{DISCUSSION}

Gonad maturation is a continuous process. Thus, dividing it into distinct stages always leads to controversy and, therefore, demands the use of adequate tools to describe and differentiate such stages. The gonad maturation process in Haliotis has been described by several authors based on histological features (Capinpin et al., 1998; Sobhon et al.; Najmudeen \& Victor; Setyono), which is the most reliable approach (Jaramillo \& Navarro, 1995).

However, in this investigation we were able to validate macroscopic features that occur in parallel with histological characteristics as, in general, the gonad maturation process is characterized by a steady increase in the number of cells and their maturation within the gonad, which in turn leads to an increase in gonad size that is easy to appreciate to the naked eye. Another noticeable feature is that, due to the transport of nutrients from the hepatopancreas to the gonad, hepatopancreas size decreases accordingly. The color of the gonad changes as cells mature inside it, thus allowing the recognition of different stages based on macroscopic features.

This sort of descriptions have been successfully used in fish species such as Clarias ngamensis Castelnau 1861 and C. gariepinus Burchell, 1822 (Mokae et al., 2013), in which macroscopic gonad characteristics have been used to recognize males; in crustaceans such as Parastacus defossus Faxon, 1898 (Noro et al., 2008) and Aegla platensis Schmitt, 1942 (Sokolowicz et al., 2007), in which the gonad maturation process has been described in terms of changes in the histological characteristics and coloration of the gonad; and in other mollusks such as the giant squid Dosidicus gigas d'Orbigny, 1835 (Diáz-Uribe et al., 2006), in which cell morphometry has been used to differentiate between gonad maturation stages by comparison with external features, and gastropods such as Strombus gigas Linnaeus, 1758, in which various macroscopic and histological features have been described for different maturation stages (Aldana Aranda $e t$ al., 2003). Najmudeen \& Victor even considered macroscopic features such as gonad color and percent coverage in the conical appendage, for the study of Haliotis varia Linnaeus, 1758.

The complexity of studies like the one reported here varies between species and in relation to the difficulty in identifying gonad maturation stages at first glance. However, the characteristics of gonad growth in Haliotis make it easy to identify the different maturation stages, as confirmed at the histological level. This allows using the morphochromatic scale to recognize, in a reliable and practical manner, the different maturation stages without the need to conduct the more time-consuming histological analyses.

\section{ACKNOWLEDGEMENTS}

The authors gratefully acknowledge the support received from SAGARPA-CONACYT, through grant 01163322 coordinated by the CRIP-La Paz; CICIMAR-IPN, through grant SIP20121218; and CRIP-La Paz for POABentónicos grants in 2012, 2013 and 2014. The authors also thank the Fisheries Cooperative Societies "Bahía Tortugas", "Emancipación", "California de San Ignacio" and "Progreso" for sample collection, and researchers from CRIP-La Paz (Mr. Carlos Monroy, Dr. Eduardo Quiroz, Mr. Mauro Guadarrama and Dr. Verónica Fernández) for processing biological material. We also thank Ms. Blanca Sabrina Mancilla Arellano for image processing. María Elena Sánchez Salazar contributed to the preparation of the English manuscript. R. Sánchez-Cárdenas thanks the support from Cátedras CONACyT programme.

VÉLEZ-ARELLANO, N.; GARCÍA-DOMÍNGUEZ, F. A.; LLUCH-COTA, D. B.; GUTIÉRREZ-GONZÁLEZ, J. L. \& SÁNCHEZ-CÁRDENAS, R. Validación histológica de las fases morfocromáticas de maduración gonádica del abulón azul (Haliotis fulgens) Philippi, 1845 y del abulón amarillo (Haliotis corrugata) Wood, 1828. Int. J. Morphol., 33(3):1054-1059, 2015.

RESUMEN: La determinación de la fase de madurez es importante para identificar la temporada de desove y permitir establecer medidas de manejo pesquero para el aprovechamiento responsable de los recursos como el abulón. El presente trabajo valida histológicamente una escala de maduración gonádica a manera de guía de identificación, que consiste de cuatro fases morfocromáticas para hembras y machos (desarrollo, madurez, desove y reposo), y un estadio para los organismos reproductivamente inactivos (indiferenciado). Dada la similitud entre las características morfocromáticas de Haliotis fulgens y Haliotis corrugata, la escala de maduración gonádica puede ser utilizada indistintamente.

PALABRAS CLAVE: Herramientas de evaluación; Gametogénesis; Gónadas; Reproducción. 
VÉLEZ-ARELLANO, N.; GARCÍA-DOMÍNGUEZ, F. A.; LLUCH-COTA, D. B.; GUTIÉRREZ-GONZÁLEZ, J. L. \& SÁNCHEZ-CÁRDENAS, R. Histological validation of morphochromatically-defined gonadal maturation stages of green abalone (Haliotis fulgens) Philippi, 1845 and pink abalone (Haliotis corrugata) Wood, 1828. Int. J. Morphol., 33(3): 1054-1059, 2015.

\section{REFERENCES}

Aldana Aranda, D.; Baqueiro Cardenas, E.; Martinez Morales, I.; Ochoa Baez, R. I. \& R Brule, T. Gonad behavior during peak reproduction period of Strombus gigas from Banco Chinchorro. Bull. Mar. Sci., 33(1):241-8, 2003.

Boolootian, R. A.; Farmanfarmaian, A. \& Giese, A. C. On the reproductive cycle and breeding habits of two western species of Haliotis. Biol. Bull., 122(2):183-93, 1962.

Cox, K. W. California Abalones, Family Haliotidae. The Resources Agency of California, Department of Fish and Game. Marine Resources Operations. Fish. Bull., (118):1-133, 1962.

Diaz-Uribe, J. G.; Hernández-Herrera, A.; Morales-Bojórquez, E.; Martínez-Aguilar, S.; Suárez-Higuera, M. C. \& HernándezLópez, A. Validación histológica de los estadios de madurez gonádica de las hembras de calamar gigante (Dosidicus gigas) en el Golfo de California, México. Cienc. Mar., 32(1A):23-31, 2006.

García-Esquivel, Z.; Montes-Magallón, S. \& González-Gómez, M. A. Effect of temperature and photoperiod on the growth, feed consumption, and biochemical content of juvenile green abalone, Haliotis fulgens, fed on a balanced diet. Aquac., 262(1):129-41, 2007.

Hadijah, H.; Tuwo, A.; Litaay, M. \& Indrawati, E. The reproductive aspect of tropical Abalone (Haliotis asinina $\mathrm{L}$.) in the waters of Tanakeke Islands at South Sulawesi. Aquat. Sci. Technol., 1(2):30-43, 2013.

Humason, G. L. Animal Tissue Techniques. 4th ed. San Francisco, W. F. Freeman \& Company, 1979.

Jaramillo, R. \& Navarro, J. Reproductive cycle of the Chilean ribbed mussel, Aulacomya ater (Molina, 1782). J. Shellfish Res., 14(1):165-72, 1995.

Martin, G. G.; Romero, K. \& Miller-Walker, C. Fine structure of the ovary in the red abalone Haliotis rufescens (Mollusca: Gastropoda). Zoomorphology, 103(2):89-102, 1983.

Mokae, L. M.; Smit, N. J. \& Wagenaar, G. M. Comparative histomorphological assessment of the testes of two Clarias species from the Okavango Delta Panhandle, Botswana. Tissue Cell, 45(1):7-20, 2013

Najmudden, T. M. \& Victor, A. C. C. Reproductive biology of the tropical abalone Haliotis varia from Gulf of Mannar. J. Mar. Biol. Ass. India, 46(2):156-61, 2004.

Noro, C.; López-Greco, L. S. \& Buckup, L. Gonad morphology and type of sexuality in Parastacus defossus Faxon 1898, a burrowing, intersexed crayfish from southern Brazil (Decapoda: Parastacidae). Acta Zool. (Stockholm), 89(1):5967, 2008.
Rogers-Bennett, L.; Dondanville, R. F. \& Kashiwada, J. Size specific fecundity of red abalone (Haliotis rufescens): evidence for reproductive senescence? J. Shellfish Res., 23(2):553-60, 2004.

Roux, A.; Lambrechts, H. \& Roodt-Wilding, R. Reproductive Histology of Cultured Haliotis midae (Linnaeus, 1758) and Preliminary Evaluation of Maturation. J. Shellfish Res., 32(1):143-153, 2013.

Setyono, D. E. D. Reproductive aspects of the tropical abalone, Haliotis asinina, from Southern Lombok Waters, Indonesia. Mar. Res. Indones., (30):1-14, 2006.

Shepherd, S. A. \& Laws, H. M. Studies on southern Australian abalone (Genus Haliotis). II. Reproduction of five species. Aust. J. Mar. Freshw. Res., 25(1):49-62, 1974.

Singhakaew, S.; Seehabutr, V.; Kruatrachue, M.; Stretarugsa, P. \& Romratanapun, S. Ultratructure of male germ cells in the testes of abalone, Haliotis ovina Gmelin. Molluscan Res., 23(2):109-21, 2003.

Sobhon, P.; Apisawetakan, S.; Chanpoo, M.; Wanichanon, C.; Linthong, V.; Thongkukiatkul, A.; Jarayabhand, P.; Kruatrachue, M.; Upatham, S. E. \& Poomthong, T. Classification of Germ Cells, Reproductive Cycle and Maturation of Gonads in Haliotis asinina Linnaeus. Sci. Asia, 25(1):3-21,1999.

Sokolowicz, C. C.; López-Greco, L. S.; Gonçalves, R. \& BondBuckup, G. The gonads of Aegla platensis Schmitt (Decapoda, Anomura, Aeglidae): a macroscopic and histological perspective. Acta Zool., 88(1):71-9, 2007.

Wood, A. D. Aspects of the biology and ecology of the South African abalone Haliotis midae Linnaeus, 1758 (Mollusca Gastropoda) along the eastern Cape and Ciskei coast. Thesis Master of Science. Grahamstown, Rhodes University, 1993.

\section{Correspondence to: \\ Dra. Rebeca Sánchez-Cárdenas \\ Académico Cátedras CONACyT \\ Facultad de Ciencias del Mar \\ Universidad Autónoma de Sinaloa \\ Sinaloa \\ MÉXICO}

\section{Email: rsanchez@uas.edu.mx}

Recibido : 23-03-2015

Aceptado: 02-06-2015 